\title{
The Role of Media in the COVID-19 Pandemic Period in terms of Effective Health Care Management
}

\author{
Etkin Bir Sağlık Yönetimi Açısından COVID-19 Pandemisi Döneminde Medyanın Rolü
}

\author{
Elif KIRAN ${ }^{1}$ \\ (D) 0000-0002-8039-3822 \\ Adem BÖLÜKBAŞI ${ }^{2}$ \\ (D) 0000-0001-9795-6508
}

\begin{abstract}
${ }^{1}$ Namık Kemal University Faculty of Arts and Sciences Department of Sociology, Tekirdağ, Turkey

${ }^{2}$ Bandırma Onyedi Eylül University Faculty of Health Science Department of Social Work, Balıkesir, Turkey
\end{abstract}

\begin{abstract}
Aim: In this study, it was aimed to handle the role of the media from a sociological point of view focusing on the management of the coronavirus pandemic and the crisis caused by this pandemic, with an effective health management.

Material and Methods: In this study, the qualitative method has been adopted, and online ethnography and visual document analysis techniques have been used. For this purpose, visual and written materials, and mottos were examined in cyberspace and in conventional media.

Results: Media has a significant role in managing health care effectively during the pandemic since it has the instruments to influence individuals and public. However, both conventional and new media ignores the social and economic disparities but underlines the personal dimension instead by creating an infodemic situation and using the pandemic as a source of info-tainment in their representations regarding coronavirus disease 2019 (COVID-19).

Conclusion: It is concluded that mass media has been a very frequently used tool for getting and sharing information since the very beginning of the pandemic. Therefore, it is clear that objective and correct information provided by the media is vital for an effective health care management during the pandemic. However, the manipulative facade of media is very vivid on especially the issues of ignoring inequalities, burdening the individual with the whole responsibility of his/her health behaviors, conveying conspiracy theories and leading to an infodemic.

Keywords: COVID-19; pandemic; health care management; media; infodemic; info-tainment.
\end{abstract}

ÖZ

Amaç: Bu çalışmada, koronavirüs pandemisi ve bu pandeminin yol açtığı sağlık kriziyle mücadelenin etkin bir sağlık yönetimi ile yürütülmesinde medyanın sahip olduğu rolün sosyolojik bir bakış açısıyla ele alınması amaçlanmıştır.

Gereç ve Yöntemler: Bu çalışmada, nitel yöntem benimsenmiştir ve çevrimiçi etnografi ve görsel doküman analizi teknikleri kullanılmıştır. Bu amaçla hem konvansiyonel medyadaki hem de yeni medyadaki görsel ve yazılı materyaller ve sloganlar incelenmiştir.

Bulgular: Bireyleri ve halkı etkileyecek araçlara sahip olduğu için medyanın pandemi sürecinde sağlık hizmetlerinin etkili bir şekilde yönetilmesinde de büyük bir role sahip olduğu görülmüştür. Bununla birlikte, hem konvansiyonel hem de yeni medyanın sosyal ve ekonomik eşitsizlikleri göz ardı ettiği, bunun yerine sorunun kişisel boyutunu öne çıkardığı, kirli bilgi akışına yol açan infodemik bir durum yarattığı ve koronavirüs hastalığı 2019 (coronavirus disease 2019, COVID-19) ile ilgili sunumlarında pandemiyi bir hab-eğlence kaynağı olarak kullandığı ortaya konulmuştur.

Sonuç: Pandeminin başlangıcından beri kitle iletişim araçlarının bilgi almak ve bilgi paylaşmak için çok sık kullanılan araçlar olduğu sonucuna ulaşılmıştır. Bu bağlamda, pandemi sürecinde etkin bir sağlık yönetimi yürütülebilmesi için medyanın objektif ve doğru bilgilendirme yapmasının oldukça önemli olduğu sonucuna varılmıştır. Bununla birlikte, medyanın manipülatif yönü, özellikle eşitsizlikleri görmezden gelme, sağlık davranışlarının tüm sorumluluğunu bireye yükleme, komplo teorilerini yayma, aktarma ve bir infodemiye yol açma konularında çok belirgindir.

Accepted / Kabul Tarihi : 02.03.2021 Available Online / Anahtar kelimeler: COVID-19; pandemi; sağlık yönetimi; medya; infodemi; hab-eğlence. 


\section{INTRODUCTION}

The coronavirus disease 2019 (COVID-19) epidemic disease caused by the severe acute respiratory syndrome coronavirus 2 (SARS-CoV-2) has emerged as an unprecedented health problem in the modern world and was declared a pandemic (global epidemic) by the World Health Organization (WHO) on March 11, 2020. Since this date, all countries have enforced lockdowns for certain periods due to the epidemic that has turned into a pandemic that affects all countries in the world. While many people lost their lives because of this epidemic, the world has faced a multidimensional crisis in social, economic, political and cultural aspects. In the face of the suddenly exploding, rapidly growing and widespread effects of the COVID-19 pandemic, many issues, which are taken for granted and not questioned before in our daily life, have been started to be discussed. It is seen that this pandemic, which affects our individual lives one by one, has an unlimited domain from the regulation of our daily life to the macro level of public health policy and economic crisis. With this unlimited impact, the global pandemic has made many historically and structurally disadvantaged nations, classes, women, the elderly and other people become more isolated and vulnerable to the effects of the crisis. This pandemic, which has turned into a global crisis, demonstrated how widespread social exclusion in the society can be and how it is, and how insufficient social inclusion policies are.

This study discusses how the COVID-19 pandemic and related issues are represented in the media. The main purpose in dealing with these media representations is to try to understand how the social aspects of the pandemic are presented to the public and what functions these presentations have. In our world surrounded by information technologies, mass media appears as the most frequently applied source of information of almost anything and everything. Therefore, it should not be surprising to observe people turning to media tools in order to catch a glimpse of the reasons and results of this worldwide health crisis. Having this precious data always in their mind, mass media utilizes all its means in the urge of conveying messages related to the virus to the public. The main claim of the study at this point is that the representation of the COVID-19 pandemic in the media has a certain politics of representation. In accordance with this representation policy, it will be tried to reveal how the pandemic and the issues related to it, which are represented in conventional media and new media channels. Within this framework of providing insights on the media tools' impact on different layers of societal issues during the COVID-19 pandemic, the study handles the issue under the headings of "ignoring disparities", "science versus infodemics", "is it something personal", "the pandemic as info-tainment". The issues to be mentioned one by one below constitute the different manifestations and parts of the general discourse that dominates the representations of COVID-19 in the media, and each should be understood in conjunction with each other, not separately because none of them is independent of the other. Each subtitle is closely related to deceptive nature of media sources.

This study handles the coronavirus pandemic from a sociological point of view focusing on the role of media in terms of managing this health crisis effectively.

\section{MATERIAL AND METHODS}

This paper discusses how the situation that emerged after the COVID-19 pandemic is represented in the media. In doing so, the politics of representation which includes how this pandemic is presented in the media and the ways of presenting this epidemic, is problematized by using the news, shared contents and other materials on conventional media and social media platforms. For this purpose, a wide range of literature concerning the theoretical and applied studies has been searched and the socio-economic data about the social dimensions of the pandemic since its global emergence last year have been analyzed. However, the main point of interest here was how the media produced social messages through the presentation of conventional and visual culture products on the pandemic. Here, visual cultural products were handled both as a onesided cultural industry product and as products produced with the joint participation of people (1).

In addition, this study has a qualitative research design and for this purpose the visual products were scanned by online ethnography technique. In this way, it could be seen what the prominent and popular posts and visuals were among the virtual communities in cyberspace, and what was included in the COVID-19 representations (2). Here, an assumption like "Act of vision is not innocent" among virtual communities in cyberspace is relied on. Therefore, the political and cultural messages behind the representations of the pandemic have been examined, based on the assumption that every look and every image presented has a policy and cultural background (3). Online ethnography on the representation of COVID-19 in the media aims to understand the behavior and ways of seeing of a group of people in the virtual environment. For this purpose, both visual materials and written materials and mottos were examined. Considering that today many people spend a considerable part of their day online and more and more people are online during the pandemic, it makes more sense to conduct an online ethnographic study. The main purpose of this study is to examine the COVID-19 representations in the media with these methods and techniques and to reveal the political and cultural meanings behind these visual and written representations.

\section{RESULTS \\ Ignoring Disparities}

News regarding health on TV and printed media has been following an increasing path recently. This increase in conveying of health information has two main points to be thought on; one of which is the translation of this information of scientific nature in an appropriate format that it can be understood by the public. However, since there exists plenty of channels and actors in the media sector targeting different layers of societies, it is not easy to control the misunderstandings of health information. The second challenge is providing all people with the essential health information they require without falling into the trap of social inequality (4). The issue of social inequality not only occupies a considerable place in terms of making health information distributed via mass media understood by all layers of the society but also about the portrayal or ignorance of social inequalities in media organs especially during a global health crisis such as the 
one of COVID-19. The debate here accommodates for whole the inequalities that vary according to variables such as race, ethnicity, region, gender, class and age throughout the pandemic. In this context, it constitutes a great importance to analyze how the representation policy that covers the inequalities that already exist in all societies on a global scale works during the pandemic.

Despite the unconcealable nature of these social inequalities which have been exacerbated during the corona virus pandemic, they do not seem to be handled frequently enough in mass media. That is to say, the representation policy in the media tries to ignore these inequalities determined in the market conditions and instead to base the representation of COVID-19 on concepts such as "good management" and "governance". It is observed that mottos such as "Life fits into home", "Stay at home", "Mask, distance, hygiene" have actually functioned as part of a liberal governmentality discourse such as the management of the pandemic and the good management of the crisis in all media representations, especially in public spot advertisements. Thus, along with the orientation of the rising fear of the crisis, it is one of the important functions of the media to process the feeling that social life, which in fact included many inequalities in "normal" conditions before the pandemic, is as if it is fair, equal and as it should be.

Media certainly has a vital impact on our pictures of the world. Especially today's era of global village provides mass media with all the equipment to convey its messages all around the world. Without doubt, this constitutes a great potential of power in itself and this power is willingly used by media tools. Schiller (5), one of the leading critics of American media, asserts that our minds are managed by authorities via productions delivered by different media organs. He depicts mass media as a tremendous tool of manipulation adding the fact that "the means of manipulation are many, but, clearly, control of the informational and ideational apparatus at all levels is essential". From a technologic deterministic point of view, one can claim that the information technologies making possible the progress in communication systems are of a core importance for all social issues. That is to say, the information produced and delivered by media organs have the potential to divert public attention from one point to another. Therefore, it is a natural outcome that mass media plays a big role in reflection of such a devastating health crisis as the corona virus pandemic. As it is highlighted above, media is mostly criticized for being manipulative and for sweeping the reality under the rug. The period of pandemic is no different from this general understanding of media in the way that an indispensable social problem such as inequalities has been ignored in most programs digging the crisis and all segments of the society have been expected to obey the curfews and other limitations during this period. In other words, the socioeconomic components of health care seem to be neglected. Engels's- one of the pioneers to delve into the economic disparities in the societyaffirmation is a vivid questioning of the connection between inequality and health: "How is it possible, under such conditions, for the lower class to be healthy and long lived? What else can be expected than an excessive mortality, an unbroken series of epidemics, and a progressive deterioration in the physique of the working population? Let us see how the facts stand" (6).

Despite Beck's (7) famous quote saying that poverty has a hierarchical nature whereas air pollution is democratically distributed all over the world, the virus, which is a flesh and bone form of modern risks, doesn't follow an equal pathway of influence among people of all segments. However, this realm is seemed to be neglected in mass media. Whereas "being poor is in itself a health hazard" (8), media's inclination is directly in line with the neoliberal approach to health issues which is an understanding putting forward the idea that individuals are the one and only responsibility holders of their own status of health.

Despite the huge number of works in the literature indicating that the coronavirus pandemic has exacerbated the inequalities in the society (9-11) not only conventional but also new media channels are full of messages implying that everyone should stay home regardless of their occupation, age, gender etc. One of the items in this long list is celebrities' images having fun at home either alone or with their families. These faces of influencers from the high socio-economic classes have been tried to be instrumentalized for the aim of showing people that it is possible to stay at home and have fun at the same time $(12,13)$. However, the place they call "home" is most of the time different from the one of low social classes. To put it differently, being economically advantaged brings together several chances one of which is living in a large house and survive for a long period of time even without actively working by leaning on previous savings. As opposed to these rich people, low socio-economic groups usually do not have the chance of "having fun" at home because of a plenty of reasons such as not having a private space of their own, poor heating conditions, crowded families, and a mind occupied with the obligation of going out to work and make money for survival. In addition to these images, people with happy faces and alternative socializing ways and the photos of ordinary people who manage to stay home and still inventing new ways of adaptation to the curfews by playing an instrument on their balconies or playing games together with their neighbors from one balcony to the other have been distributed via different media channels $(14,15)$. No doubt, these are only short instances of these people's lives which continue under harsh conditions which have resulted from the corona virus restrictions. However, mass media representations of the COVID-19 pandemic are mostly covering these short instances while ignoring the social disparities of the real life behind these bits and pieces.

The elderly is another disadvantaged social group of the pandemic since being infected by the virus is a greater risk for the people aged 65 and over. In addition to the great fear of the virus that is created mostly by media, the restrictions to curb the spread of the virus have also been targeted to the elderly for the majority of this period. This situation has led to several ageist behaviors towards people of old age who have been humiliated and stigmatized by these attitudes. In opposition with this negative picture regarding the elderly, media representations of them depicts the atmosphere they are living in as a pleasant one most of the time $(16,17)$. 


\section{Science versus Infodemic}

The proliferation of conspiracy theories is one of the most common cases of COVID-19 representation in the media. First of all, modern rational societies have returned more towards conspiracy theories that claim to explain everything after the emergence of this pandemic. For example, in the period prior to the virus's first appearance in Turkey some medical doctors awkwardly claimed that "this virus doesn't infect the people who have the Turkish gene" or some others offered strange measures and treatments under the name of alternative medicine. In this process mediatic representations regarding COVID-19 became very functional. Bestselling books and programs that deal with many conspiracy theories that this virus and the vaccines planned to be made as a result are part of a global experiment or conspiracy aimed at minimizing the population, robotizing and enslaving humanity started to show. The society, which has experienced a complete anomic situation about what is right or wrong, what is "real science" and what is "pseudoscience" began to frequently see conspiracy theorists in their roles as a strategist, futurologist, communication consultant etc. COVID-19 is different from previous pandemics in that it is the first pandemic of the post-truth period. Post-truth era is a period when objective facts and scientific facts are much less effective than emotions and personal convictions in shaping public opinion. Therefore, the COVID-19 pandemic, which emerged under post-truth conditions and created great uncertainties in such an environment, pushed people into a panic. The greatest promise of modernity to humanity and one of its greatest achievements was that it enabled the modern individual to predict her own future by virtue of the scientific progress. However, it is witnessed that public belief in modern science has been shaken by such a global pandemic processes that create great uncertainty and panic, and this situation is abused by the media that directs the public opinion.

In this process, some politicians and mediatic celebrity figures all over the world have displayed an anti-scientific attitude in public discourse. For example, the statements of Brazilian President Bolsonaro or US President Trump can be cited as examples of this (18). Especially in the case of Trump, this anti-science attitude was managed with a posttruth effect built with the messages he gave to the public on social media channels such as Twitter (19). For example, he wrote "we learned to live with "flu season", just like we are learning to live with COVID-19, in most populations far less lethal!!!" (20). This type of messages is totally manipulating because these messages are completely contrary to the facts scientists have put forth about COVID-19. In a short time, anti-science discourse was created, which paved the way for the writing of many popular books based on conspiracy theories rather than scientific facts, and similar news programs in the media. Another dimension of the anti-science discourse built with conspiracy theories is that some "expert" people frequently appear in the media with titles such as oracle, astrologers, life coach, strategists, and spiritual leader. These people, whom we can generally call prophecy masters, take part in both news programs and the health, daily life and magazine programs of televisions throughout the day. At the beginning of 2020, in one of the mostwatched mainstream television channels in Turkey, astrologers commented on which events will happen in 2021. The "predictions" of these astrologers for 2020 were presented to the public in the media as a truth prophecy. People are now feeling psychologically helpless and exhausted in the face of the long-lasting effects of the pandemic (deaths, illnesses, concerns about people's families and relatives, the stress caused by the lockdown), and they have started to believe in prophecies.

As mentioned before, these kinds of prophecies, and their representations in media do not address reason and knowledge, but emotions like fear and hope in accordance with the spirit of the post-truth era. For example, the following headline in an Indian newspaper and a prophecy show very well how their masters position themselves: "Soothsayer VS Doomsayer - Astrologers back in demand as anxiety mounts in pandemic times". According to this news "seasoned astrologer P. Khurrana says: I did not make any prediction about COVID-19 as my calling is to be a soothsayer and not a doomsayer" (21). As it can be seen, the news language in the media represents this astrologer as a soothsayer that gives people good news. According to this astrologer, scientists, politicians or doctors do not know when the epidemic will end, and here astrologers step in at the point where science ends. The soothsayer (in his interview dated as March 2020) claims that only astrologers can know when the epidemic will end, and that the pandemic may only end by November 2020. The astrologer here is actually none other than the media that represents COVID-19 in a certain way. The media answers to the question "when this epidemic will end" by using astrology without the need for any scientific evidence and thus appeals to people's fears and hopes.

However, in any case, the result is that people are exposed to information pollution due to the representations about COVID-19 on social media (22). While the increase of information pollution constitutes an important factor that threatens public health on the one hand, it also serves the dominance of conspiracy theories against science. Considering in which areas infodemic is located, first of all, the issue of whether this disease exists is the most important question of the information epidemic. Numerous social media posts saying that the disease never actually existed and that it is just an ordinary flu like other flu, lead many people to believe it, just like self-fulfilling prophecy. In this case, it can be said that the representations of COVID-19 in the media almost create a hyper-reality. The virus, and also disease perception created in people's minds is now completely disconnected from reality, and thus the representations of COVID-19 function as simulacra (23). As a result of all these, both conventional media (newspaper, television etc.) and new media channels have created a new genre from this situation. This uncertainty, despair and fear caused by COVID-19 have been turned into a self-help literature genre in media. This genre should be understood as a style of media presentation in general, not just as a genre limited to literature. Especially TV shows and daytime programs tried to function as a general self-help guide during COVID-19 days (24). They claim to answer the question, "how an average middle-class person can manage daily life problems and eventually can survive these COVID-19 days?". 


\section{Is It Something Personal?}

Soon after the burst of COVID-19, mass media showed a drastic change in terms of its core issues of debate and corona virus effect both in national and international level has become the leading agenda (25). All these issues depicting the COVID-19 process as if it is something that the individual is bound to fight by himself/herself remind the neoliberal transformation in all layers of public life including the one of health. In the neoliberal understanding of health, human beings bear the whole responsibility of their deeds and they are to face all the consequences of their behaviors or choices that are giving harm to their health. Therefore, the informative and imperative language that is directed to individuals during the pandemic is burdening people with a heavy load which has the potential of bursting out with social, economic or psychological problems in return. This is a step which transforms the leading powers' responsibilities onto the self. That is to say, pushing the individual to shoulder the burden of his/her status of health eases the situation for society in the way that the individual is seen as the sole responsible one for the public health problems and the deviations regarding the "tears in the social fabric" become obsolete (26). In order to dig into the depths of this debate in the framework of its representation in mass media, the intersection of individualism and health should be shed a bright light onto. Bauman (27) asserts that being individual appears as a task to be fulfilled in modern societies. Among plenty other requirements of the modern world from the self, acting, feeling and living as an individual stands as an umbrella on top of many vital issues. Different from the classical era, individual is "embroidered" with an appraisal of having the opportunity to take the helm of his/her life with only a "tiny" expense which is taking the responsibility of all the positive and negative outcomes of this courageous attempt on his/her own. This promise of freedom remains seemingly on several occasions leaving the modern man with the gloomy atmosphere of harsh self-evaluations. If there exists an unwanted situation about the individual's deeds, s/he appears as the one to be blamed setting aside all the socioeconomic background of the individual's choice. The neoliberal approach embraces the idea that the victim and the ones defining the problem are different sides and, moreover, the problem belongs only to the individual who appears as being the victim and guilty at the same time. Following this standpoint, the people with the problem are depicted as the reasons for the problem to occur which is a lively example of labeling them with being not only the creator of problems but also the ones that deviate from social rules since they do not have enough capacity to adapt the system. Additionally, the authorities of this system are put on a higher scale since they are the ones without the problem (26). In other words, "those who fail to satisfy the conditions prescribed by policymakers can be characterized as morally irresponsible, personally culpable for their failure to take responsibility for their conduct, and as such undeserving of the benefits and opportunities afforded the "law abiding citizen" (28). This heavy burden on the individual has been so vividly reminded via mass media tools from the very beginning of the corona virus pandemic that not only broadcast media but also print, outdoor and new media are all dominated by several campaigns highlighting the importance of staying at home and taking care of their individual well-being. It is known that the opportunity of accessing to the Internet and mobile communication much easier than before and with the vast usage of social media which conveys public health messages to more people, more quickly and directly than ever (29). For that reason, lay people have been living a life surrounded by images and voices telling and showing them what to do in order to take care of their individual selves at all times during the pandemic.

It is for sure that a health crisis on such a devastating scale requires not only public authorities' but also individuals' trying to do their best on all terms. However, staying at home and leading a healthy life is a way of life for some segments of the society whereas it is just a sweet dream or a luxury for others. As it has been illuminated under the previous headings of the manuscript, inequalities have always been a part of social problems, they have been exacerbated during the pandemic, though. However, the programs presented in mass media mostly focus on staying at home regardless of the different socioeconomic status of different segments of the society. Moreover, the health authorities, who are the almost every day seen faces in each and every media organ, support this attitude. Another vital point here is that experts' constantly taking part in media in programs handling the different strategies of living in a world haunted by a virus (30). This attitude of giving tips on "dos" and "don'ts" is another way of portraying the precautions against the virus as if they are something "personal".

\section{The Pandemic as Infotainment}

As we mentioned previously, this is the first post-truth pandemic and post-truth means addressing not to reason and facts but to people's emotions like fear and hope. From the very early days of pandemic, people want to believe that this pandemic will end soon and they will return to the old normal days. This expectation of people has become the primary target of the media. This has changed both the media's representation of COVID-19 and the daily broadcast flow. In this process, the general framework of this change in the media caused by COVID-19 is the presentation of the pandemic as a kind of infotainment. Infotainment is a word which combines the information and entertainment and meaning the presentation of all news as in the form of entertaining material. Especially on mainstream televisions or hashtags and trending topics on different web applications such as Twitter or Instagram we can observe the influence of this infotainment style of journalism during pandemic days (31). This is one of the symptomatic consequences in terms of the important effects of COVID-19 on the media, apart from the representations in the media. For example, considering the rhetoric presented and disseminated in the media after the epidemic, it has been said that the return to normal days will occur as soon as possible. But unfortunately, later, it was stated that the normal days to be reached in the summer days when the epidemic subsides, will be actually a new normal, it is not possible for us to live as in the old days, but ultimately this is also a "new" normal. This feeling of "nothing will be same after the COVID-19 pandemic" created the nostalgia which means the impossibility of return to those good old days, and bittersweet longing for the past. In fact, media addressed 
this feeling of nostalgia, which is very strong in people during the COVID-19 pandemic process, and built its infotainment strategy on this.

In connection with this, it is seen that interesting developments are observed when the broadcast flow in the media is examined. For example, the "nostalgia" films that lasts almost all day has started to be broadcasted on televisions and especially on state television TRT. TV series and other TV programs from the early 2000s, 1990s and even 1980s were presented to the audience in. In addition, the general view of the representation of COVID-19 in the media in the morning and evening news and prime-time debate programs, magazine shows, game shows, religious programs and many other programs have created a language that both expresses nostalgia for the normal and insist that this will no longer be possible. In this context, the topics that are known as the daytime zone of mainstream television channels and that are mainly covered during the broadcast hours of the programs for women were adapted to the COVID-19 process. For example, personal care and cleanliness, horoscopes and all kinds of individual fortune issues related to it, healthy eating, prayers to be done against the epidemic, love life and relationships during the epidemic, and as a result of all these, the cleansing, nourishment and purification of the whole body and soul. All these actually show the representation of the "wellness" culture and life coaches who are the bearers of that culture in the media in the context of COVID-19, which aims to spread and adopt the new subjectivity that emerged in the neo-liberal period towards the middle classes through the upper-middle class and which claims to include not only physical health but also a spiritual health feeling. The frequent use of this feeling of nostalgia and wellness culture in the media constituted the content of the infotainment.

In the sphere of infotainment where news is blended with entertainment, we can see that news is commodified in such a manner that it creates an industrial cultural content. This created a new space for culture industry. Within this culture industry, the presentation of news in the form of entertainment basically serves two purposes. On the one hand, it calms people's anxieties and fears by softening a very heavy and harsh news content. On the other hand, it produces a plastic cultural product that is no longer relevant to the facts by presenting news content that is too perfected and aestheticized to be true (32). People are now watching information about the epidemic not only as news but also as a visual spectacle and entertainment in the morning magazine programs, health programs and evening prime-time news programs. Middle-class people who were at home during the lockdown process have also increasingly become a part of this spectacle (33). For example, inviting people to applaud healthcare professionals by going out on their balconies in the early days of the epidemic has become an integral part of the media's epic praise for the altruistic efforts of healthcare professionals and using it as an infotainment material.

The perception of news as entertainment and the birth of infotainment is not unique to COVID-19, but since COVID-19 is the first post-truth pandemic, the use of news about the epidemic in social media channels has created a new effect. This effect is the feeling of alienation created by people watching scientific facts or even the extremely serious death and disease news about the epidemic as if watching an entertainment program on television or social media in the face of a deadly epidemic. For example, sarcastic images are shared regarding the horoscope comments on the epidemic mentioned in the previous section. In a visual about the horoscope interpretations of COVID-19, it is said as the horoscope interpretation of all the signs on that day: "You will be spending time in your home" (34). Or, in some other images, famous people who look like a Chinese man after getting the Chinese vaccine are depicted. These images actually contain a discourse that implicitly questions the reliability of the Chinese vaccine and implies that China is involved in the conspiracy regarding the vaccine, which is claimed to be a remedy for the virus, as well as in the conspiracy to spread the virus.

In Italy, where the number of cases and deaths was high in the first days of the epidemic, people going to the balconies of their homes and singing the song Ciao Bella or the national anthem and accompanying other people with these songs and marches with their flags was one of the most used images of the media's COVID-19 representations. This image of people having fun and trying to cope with life's difficulties at the same time is the most convenient image for the infotainment spectacles of media. Because this image creates a myth that will exactly be liked by the media and reflecting the expectations and hopes of the audience: "Despite all the difficulties, troubles and evils, life continues and who knows, maybe someday the good old days will come back" (35). Every image has rhetoric and certain significations made with images refer to certain representations. What depicted here is a repraising of an ideal happy middle-class life, a sense of solidarity and unity, and in this way overcoming the challenges of the pandemic. Thus, an infotainment environment is created in which the feeling of nostalgia, which expresses longing for the good old days, is kept alive and strong, and around this feeling, way of coping with hardships of life is created by softening the heaviness of the death news and turning it into a spectacle.

\section{DISCUSSION}

Health care management is a vital issue which covers a wide range of fields some of which are medicine, economics, sociology, psychology etc. In parallel with the advances in information technologies, channels of communication have also occurred as the stakeholders of this significant effort. Starting from the last years of the 20 th century, there has been a great change in not only the production but also the delivering of information in each and every issue worldwide. As a reflection of that, a considerable amount of information on health is delivered today thanks to the developments in both biomedical sciences and telecommunication systems. Apart from the routine issues, times of drastic health phenomena appear as periods in which media acts as a shining star in terms of building the ways of connection between lay people and experts in the course of health care management. Epidemics are extraordinary periods portrayed with chaos on several realms. In the blurred atmosphere of the days with a horrible crisis people turn to media with the hope to get some information and draw their road map. The COVID-19 pandemic stands as one of the striking 
examples of the role of media in this period. This manuscript has handled the intersection of media and health care management during the COVID-19 pandemic under four headings via a deep survey of related documents and conventional and new media tools and it has revealed that the news and programs conveying via these tools mainly perpetuate the neoliberal understanding of health which gives the individual the whole responsibility of his/her health behaviors. Doing this, the media seems to ignore inequalities such as gender, age or social class which actually lie behind health status of people in many cases. Not only health authorities but also voices of other fields such as the ones of astrology, spirituality, etc. appear on screens or social media channels and keep giving people advice of getting over this chaotic period smoothly. However, the study has shown that these programs are inclined to follow a neoliberal approach which seems to erase the socio-economic determinants of health and to ignore social inequalities while giving advices about staying home, having fun at home, behaving their body and soul in a good manner by providing them with the necessary material and spiritual goods. The core point that is swept under the rug here by the media is that all these advices are in direct relation with social determinants such as age, wealth, gender, etc.

The spread of infodemic is an important drawback for the effective health care management. The negative function of the media in this process is the spread of fake news and the emergence of an infodemic along with the pandemic. In the post-truth era, fake news can become widespread much more easily. Because fake news turns into a propaganda tool with COVID-19 representations in the media, especially in such crisis periods and in a global society where communication opportunities are so abundant. As famous stage actor Coluche says, "the only thing true in a newspaper is the date of that day". So, media also manipulates scientific and factual facts about COVID-19 together with fake news. This manipulation can take place in different ways. For instance, televisions address the feelings of people who are worried about the epidemic and actually use the basic weaknesses of the post-truth era. In the chaos environment created by information pollution, the efforts of global health authorities such as WHO and national public authorities to truly combat the epidemic are weakening and facing a greater challenge. Thus, the first struggle was the struggle against the epidemic and the second was the struggle against the infodemic that produced fake news about the epidemic. Social media channels in cyberspace are places where fake news is produced easily, and the content produced here is sometimes for the purpose of making fun, providing false information or propaganda. Therefore, these media channels should be used in a positive way for effective health care management.

\section{CONCLUSION}

The concluding remarks of the article indicates that media has played a vital role during the corona virus pandemic and that this role is in direct parallel with the issue of health care management. Media tools' standpoint during this period acts as the mitigator of the ways that are and should be followed in the path of health management during the COVID-19 pandemic. The prominent impacts of both conventional and new media can be summed up under four main points which are the manipulative approach towards depicting the crisis in the framework of individuality; paving the way for an infodemic; transforming this health crisis into infotainment; ignoring the inequalities which exacerbated during the pandemic. As it is the case for each and every issue regarding media, media literacy should be a helpful pathway to be followed while acquiring and distributing information through mass media tools. As we mentioned above, the nature of the media today is based on distortion and deception. Therefore, the manner in which news about COVID-19 is presented in the media has similarly led to the rise of conspiracy theories and unscientific types of information that try to marginalize scientific knowledge. In addition, it has been seen that the media used the COVID-19 news as an infotainment material, just like the war news, and thus tabloidized the horrors of reality.

Ethics Committee Approval: Since our study was not an experimental study including human or animal subject, ethics committee approval was not required.

Conflict of Interest: None declared by the authors.

Financial Disclosure: None declared by the authors.

Acknowledgements: None declared by the authors.

Author Contributions: Idea/Concept: EK, AB; Design: EK, AB; Data Collection/Processing: EK, AB; Analysis/Interpretation: $\mathrm{EK}, \mathrm{AB}$; Literature Review: EK, AB; Drafting/Writing: EK, AB; Critical Review: EK, AB.

\section{REFERENCES}

1. Emmison JM. The conceptualization and analysis of visual data. In: Silverman D, editor. Qualitative research: theory, method and practice. London: Sage; 1998. p.246-65.

2. Skågeby J. Online ethnographic methods: towards a qualitative understanding of virtual community practices. In: Daniel BK, editor. Handbook of research on methods and techniques for studying virtual communities: paradigms and phenomena. Hershey, PA: IGI Global; 2011. p.410-28.

3. Robbins K. Into the image: culture and politics in the field of vision, London: Routledge; 1996.

4. Viswanath K. Public communications and its role in reducing and eliminating health disparities. In: Thomson GE, Mitchell F, Williams MB, editors. Examining the health disparities research plan of the national institutes of health: unfinished business. Washington, DC: Institute of Medicine; 2006. p. 21553.

5. Schiller HI. The mind managers. Boston: Beacon Press; 1973.

6. Engels F. The condition of the working-class in England in 1844. Cambridge: Cambridge University Press; 2010.

7. Beck U. Risk society: towards a new modernity. London: Sage; 1992.

8. de la Barra X. Poverty: the main cause of ill health in urban children. Health Educ Behav. 1998;25(1):46-59. 
9. Marmot M, Allen J. COVID-19: exposing and amplifying inequalities. J Epidemiol Community Health. 2020;74(9):681-2.

10. Dorn AV, Cooney RE, Sabin ML. COVID-19 exacerbating inequalities in the US. Lancet. 2020;395(10232):1243-4.

11. Beaunoyer E, Dupéré S, Guitton MJ. COVID-19 and digital inequalities: Reciprocal impacts and mitigation strategies. Comput Human Behav. 2020;111:106424.

12. aa.com.tr [Internet]. Uştuk H. Fazıl Say, Burak Özçivit ve Fahriye Evcen 'Evde kal' çağrısı yaptı. [Cited: 2020 December 2]. Available from: https://www.aa.com.tr/ tr/kultur-sanat/fazil-say-burak-ozcivit-ve-fahriyeevcen-evde-kal-cagrisi-yapti/1780050.

13. pagesix.com [Internet]. Bergen S. Celebrities show whom they stay at home for amid coronavirus pandemic. [Cited: 2020 December 5]. Available from: https://pagesix.com/2020/03/24/celebrities-showwho-they-stay-at-home-for-amid-coronaviruspandemic/.

14. sputniknews.com [Internet]. Dünyada halktan balkon ve çatılarda koronavirüse karşı direniş eylemi. [Cited: 2020 November 8]. Available from: https://tr.sputniknews.com/foto/202003171041619575 -dunyada-halktan-balkon-ve-catilarda-koronavirusekarsi-direnis-eylemi/.

15. trthaber.com [Internet]. Balkondan balkona isim-şehir oynayıp türkü söylediler. [Cited: 2020 November 17]. Available from: https://www.trthaber.com/haber/ yasam/balkondan-balkona-isim-sehir-oynayip-turkusoylediler-473258.html.

16. trthaber.com [Internet]. 4 kardeş balkondan sohbet etti. [Cited: 2020 December 12]. Available from: https://www.trthaber.com/haber/turkiye/4-kardesbalkondan-sohbet-etti-469261.html.

17. milliyet.com.tr [Internet]. Valilik duyurdu! 65 yaş ve üzeri vatandaşların sokağa çıkış saatleri değiştirildi. [Cited: 2020 December 10]. Available from: https://www.milliyet.com.tr/gundem/valilik-duyurdu65-yas-ve-uzeri-vatandaslarin-sokaga-cikis-saatleridegistirildi-6307265.

18. Duarte TR. Ignoring scientific advice during the COVID-19 pandemic: Bolsonaro's actions and discourse. Tapuya: Lat Am Sci Tech Soc. 2020;3(1):288-91.

19. Frickel S, Rea CM. Drought, hurricane, or wildfire? assessing the Trump administration's anti-science disaster. Engaging Science, Technology and Society. 2020;6:66-75.
20. bbc.com [Internet]. Trump Covid post deleted by Facebook and hidden by Twitter. [Cited: 2020 December 19] Available from: https://www.bbc.com/ news/technology-54440662.

21. hindustantimes.com [Internet]. Dutt N. Soothsayer vs doomsayer: Astrologers back in demand as anxiety mounts in pandemic times. [Cited: 2020 December 10]. Available from: https://www.hindustantimes.com/ cities/soothsayer-vs-doomsayer-astrologers-back-indemand-as-anxiety-mounts-in-pandemic-times/storyYS5bCqMccvjNnTGubhoyJI.html.

22. medium.com [Internet]. Wardle C. Fake News; It's complicated. [Cited: 2020 December 15]. Available from: https://medium.com/1st-draft/fake-news-itscomplicated-d0f773766c79.

23. Baudrillard J. Simulation and simulacra. Ann Arbor: University of Michigan Press; [1981] 1994.

24. Yılmaz Gümüş V. Self-help literature in Turkey from the perspective of translation studies. International Journal of Social Inquiry. 2017;10(2):93-116.

25. Vatandaş S. COVID-19 pandemia and newspaper cuffs from the 'agenda determination' function. Sosyal Bilimler Metinleri. 2020;1:61-78.

26. Wallack L, Dorfman L, Jernigan D, Themba-Nixon M. Media advocacy and public health: power for prevention. California: Sage Publications; 1993.

27. Bauman Z. Liquid life. Cambridge: Polity; 2005.

28. Brown BJ, Baker S. Responsible citizens: individuals, health and policy under neoliberalism. London: Anthem Press; 2013.

29. Mcnab C. What social media offers to health professionals and citizens. Bull World Health Organ. 2009;87(8):566.

30. showturk.com [Internet]. Koronavirüsle savaşan buğu. [Cited: 2020 December 5]. Available from: https://www.showturk.com.tr/programlar/video/koron avirusle-savasan-bugu/702125.

31. Thussu DK. News as entertainment: The rise of global infotainment. London: Sage; 2007.

32. Adorno TW. The cultural industry: selected essays on mass culture. London: Routledge; 1991.

33. Debord G. The society of the spectacle. Detroit: Red and Black; 1977.

34. nobleworld.co.uk [Internet]. BLT (2-Apr) motivation: How to keep yourself 'up'. [Cited: 2020 December 10]. Available from: https://www.nobleword.co.uk/blt-2apr-motivation-how-to-keep-yourself-up/.

35. Barthes R. Mythologies. London: Paladin Books; 1972. 